\title{
STRATEGI PENGEMBANGAN BMT (BAITUL MAAL WA TAMWIL) DALAM MEMBERDAYAKAN USAHA KECIL MENENGAH
}

\author{
Ely Siswanto \\ Fakultas Ekonomi Universitas Negeri Malang \\ J1. Surabaya No.6 Malang-65145. Telepon 0341-551312 pes.552888 \\ Website: http:/www.Malang.ac.id
}

\begin{abstract}
The sustainability of syariah microfinance institution depends on the organization it professionally, and the strategic implementation comprehensively in positioning BMT (Baitul Maal wa Tamwil) as one of microfinance intermediary institution. The BMT's existence created positive public image to participate in developing BMT and improving people wealth broadly. Optimism toward BMT's prospect is a main capital in developing BMT concept not only as a development agent, but also as a profit institution who financing of small business enterprise actively. The aim of this research is : 1)to identified and analyst BMT's model which can develop the potential of small business enterprise; 2) to describe $B M T$ 's effort to develop potency of small business enterprise.

The result of this research is that BMT development strategy tend to financial viability oriented, institutional soundness oriented and social effect oriented. These strategy must be supported by ability of figh and economic analysis and enough resources. Internally, institutional soundness toward financial management and managerial aspect must be increased by BMT to make small business financing efficiently.
\end{abstract}

Keyword: development strategy, BMT, small business enterprise empowerment

Pengembangan sektor keuangan memiliki pengaruh yang luas dalam menstimulasi perekonomian sektor riil (finance led growth), dimana penyebaran kredit dapat terdistribusi secara merata melalui optimalisasi fungsi intermediasi lembaga keuangan. Perkembangan sektor keuangan di Indonesia telah mengalami segmentasi diantara sektor keuangan formal dan informal, hal ini diakibatkan karena ketidakmampuan sektor keuangan formal (perbankan) dalam memberikan fasilitas jasa keuangan bagi masyarakat lapisan bawah (miskin). Terdapat berbagai alasan sosial dan ekonomis yang mendasari sektor formal kesulitan untuk mengakses sektor informal, seperti : tingginya risiko kredit dan ketidaktersediaan jaminan (Collateral) yang cukup untuk melapisi kredit. Selain itu tingginya biaya transaksi (Transaction cost) serta hambatan sosial dan budaya seperti : tingkat pendidikan yang rendah (ketidakmampuan melakukan financial record terhadap aktivitas ekonomi mereka) 
menyebabkan sektor formal semakin enggan untuk melakukan penetrasi di sektor informal. Namun keadaan inilah yang memicu berkembangnya sektor-sektor keuangan informal, yang popular dengan istilah microfinance, untuk berpartisipasi dalam pembiayaan bagi masyarakat lapisan bawah.

Grameen bank, sebagai salah satu contoh konsep microfinance konvensional yang berhasil dalam mengembangkan social capital sebagai pengganti agunan (Collateral) dan dianggap telah mampu memecahkan permasalahan biaya transaksi (transaction cost) akibat tingginya asymmetry information (informasi asimetris) di sektor informal, sesungguhnya sangat masih terkesan minim memperhatikan prospek dan kemampuan finansial klien. Hal ini disebakan karena penentuan biaya modal dilakukan lebih dahulu (predetermined interest rate) dengan hanya mempertimbangkan biaya modal/cost of fund (internal side), dan kurang memperhatikan kemampuan finansial dari prospek usaha klien (external side). Sehingga hal tersebut mengurangi insentif pihak yang meminjamkan (lender) untuk melibatkan diri secara langsung dalam pengembangan usaha klien karena pengembalian return riba yang sifatnya tetap.

Syariah, sebagai alternatif solusi dalam merenovasi program microfinance didasarkan atas konsep bagi hasil (profit sharing) yang mendorong keterlibatan pihak lender atas prospek dan kemampuan finansial klien. Namun keberlangsungan konsep syariah tidak luput dari pemahaman yang utuh dan pengaplikasian yang komprehensif atas hukum-hukum religius (moral dan etika). Hubungan kemitraan (mutual investor relationship) yang dibangun atas dasar perspektif islam dalam ekonomi syariah dimana masing-masing pihak berusaha untuk saling berperan dalam menciptakan keadaan yang lebih baik dengan berupaya secara maksimal untuk memperkecil risiko kegagalan usaha dengan berpegang teguh pada prinsip kehati-hatian. Selain itu sistem keuangan syariah diyakini sangat memperhatikan azas kemaslahatan bagi orang banyak, sehingga pembiayaan yang ditopang oleh lembaga keuangan mikro syariah harus menghindari kemungkinan hal-hal yang merusak moral masyarakat dan lingkungan serta harus memenuhi kriteria halal menurut syariah islam. Selain itu setiap transaksi yang dibiayai oleh lembaga keuangan mikro syariah harus berorientasi langsung terhadap sektor riil sehingga sangat jelas bahwa dalam sistem keuangan syariah terjadi sinkronisasi antara perkembangan lembaga keuangan dan produktifitas di sektor riil.

BMT sebagai salah satu institusi microfinance syariah di Indonesia, saat ini mengalami tren perkembangan yang semakin baik bila dilihat dari perkembangan aset dan penyaluran 
dananya. Jumlah BMT di Indonesia sekitar 2,470 dengan jumlah anggota 330.000, dan penyaluran pinjaman hingga 187 milyar rupiah (Bank Indonesia). Jumlah BMT semakin meningkat pesat dari tahun ke tahun, awal 1995 jumlah BMT hanya sekitar 300 di seluruh Indonesia. Pada tahun 1996 jumlahnya bertambah hingga 700, dan pada akhir 1997 jumlahnya semakin meningkat hingga mencapai 1,501 buah.

Strategi pengelolaan keuangan BMT harus terfokus pada penyelenggaraan skim pembiayaan yang tepat dan disesuaikan dengan kebutuhan klien dan kondisi market di pasar keuangan informal. Minimnya aset jaminan dari sebagian besar klien, sesungguhnya merupakan keterbukaan risiko yang harus diantisipasi oleh BMT. Sehingga dalam setiap pengajuan dan persetujuan pembiayaan harus dilewati dengan tahap-tahap prinsip kehatihatian. Di sisi lain BMT harus banyak melakukan penggalian informasi yang relevan dengan keadaan klien, dan prospek usaha sehingga mendukung informasi atas kemampuan finansialnya. Sehingga keberlanjutan usaha klien dapat terjaga dan proses penagihan bagi hasil tidak menganggu aktivitas usaha klien.

Pembiayaan microfinance syariah yang lebih variatif dibandingkan dengan microfinance konvensional, sesungguhnya dapat dijadikan basis kekuatan dalam mendiversifikasikan risiko portofolio asset BMT (Siregar, 2001). Namun hal tersebut harus diimbangi dengan penyesuaian risiko dan return, serta pembenahan piranti yang tepat dalam proses screening dan monitoring klien yang prospektif. Selain itu kemampuan pengelola BMT untuk memahami kesesuaian jenis pembiayaan dan karakteritik usaha klien, juga harus ditingkatkan untuk menjamin konsistensi keberlangsungan pembiayaan dan performa institusi secara umum.

Keberlangsungan dan kemajuan institusi microfinance tentunya tidak terlepas dari pengorganisasian yang professional, dan pengimplementasian strategi yang komprehensif dalam memposisikan BMT sebagai salah satu institusi intermediasi keuangan mikro yang praktis dan diminati oleh masyarakat. Hal ini merupakan stimulasi dalam pengembangan BMT kedepan agar konsisten dalam merealisasikan pembiayaan dan pendanaan bagi aktivitas ekonomi masyarakat khususnya masyarakat lapisan bawah. Sehingga eksistensi BMT tersebut, dapat melahirkan image positif masyarakat untuk terus berpartisipasi dalam mengembangkan BMT sekaligus memperbaiki kehidupan sosial ekonomi masyarakat yang lebih luas. Proses inilah yang mendasari optimisme kami untuk mengembangkan konsep BMT sebagai agen pembangunan, sekaligus sebagai institusi profit yang aktif dalam pendanaan bagi usaha kecil. 
Tujuan yang ingin dicapai dalam penelitian ini adalah : 1) untuk mengidentifkasi dan menganalisis model BMT yang dapat memberdayakan potensi usaha kecil; 2) untuk mengetahui upaya yang bisa dilakukan agar BMT berhasil dalam memberdayakan potensi usaha kecil menengah. Penelitian ini diharapkan memiliki kontribusi dalam 1) menambah wawasan peneliti mengenai khususnya mengenai problematika dan upaya pengembangan BMT dan dampaknya terhadap usaha kecil; 2) sebagai sumber informasi dan menambah pengetahuan bagi semua pihak yang hendak mengadakan penelitian lebih lanjut terhadap halhal yang belum terungkap dalam penelitian ini; 3) sebagai bahan masukan bagi Lembaga Keuangan Mikro, khususnya Lembaga Keuangan mikro Syariah dalam rangka peningkatan dan pengembangan institusi sehingga akan mencapai tingkat keberhasilan yang optimal.

\section{METODE}

Jenis penelitian yang digunakan dalam penelitian ini adalah penelitian deskriptif. Tujuan dari penelitian deskriftif adalah untuk membuat deskripsi, gambaran, atau lukisan secara sistematis, faktual dan akurat mengenai fakta-fakta, sifat-sifat, serta hubungan antar fenomena yang diselidiki.

Usaha mendeskripsikan fakta-fakta itu pada tahap permulaan tertuju pada usaha mengemukakan gejala-gejala secara lengkap di dalam aspek yang diselidiki, agar jelas keadaan atau kondisinya. Lebih dari itu penelitian ini berusaha untuk mengembangkan suatu konsep mengenai strategi pengembangan lembaga keuangan syariah dalam memberdayakan potensi usaha kecil serta untuk memberikan konstribusi pemikiran terhadap lembaga keuangan syariah. Fokus penelitian ini hanya berorientasi pada pengembangan strategi internal LKMs dan pengaruhnya terhadap usaha kecil.

Teknik pengumpulan data yang digunakan didalam penelitian ini adalah studi literatur dan data hasil penelitian yang berkaitan dengan tema yang diambil dalam penelitian ini. Dengan instrumen penelitiannya adalah dokumentasi yaitu artikel yang terdapat pada majalah, koran, dan internet serta literatur lain seperti buku maupun jurnal yang sesuai dengan permasalahan yang diteliti.

Penelitian ini menggunakan teknik analisis Analisa Isi Tema (Thematick Contein Analysis). Menurut Calire (2002, dalam Marliyana 2002) analisa isi tema ini digunakan untuk 
mengidentifikasi dua perbandingan. Untuk analisis yang dimaksudkan membedakan tersebut, ia membaginya dalam lima langkah yaitu : 1) review literatur dan interview guide (pedoman wawancara); 2) Interview, meringkas, feed back terhadap hasil-hasil ringkasan yang diperoleh; 3) melakukan analisis pararel dengan peneliti-peneliti lain; 4) membandingkan hasil dalam interpretasi dengan peneliti lain; dan 5) interpretasi dan pengambilan keputusan.

Karena teknik data yang dilakukan dalam penelitian ini adalah kajian literatur, maka analisa isi tema yang dilakukan tidak dengan melalui interview. Oleh karena itu, teknik yang digunakan adalah review literatur yang diringkas dan feed back terhadap hasil-hasil ringkasan yang diperoleh yang kemudian dianalisis dan diinterpretasikan.

\section{PEMBAHASAN}

Keberlanjutan program microfinance syariah membutuhkan pemahaman yang komprehensif terhadap keadaan internal institusi dan pengaruh eksternal, yang membawa dampak pada perubahan strategi yang tepat pada tujuan utama institusi. Oleh karena itu setiap strategi yang dimunculkan, selayaknya berorientasi pada kesesuaian dengan perubahan lingkungan, persaingan dan keadaan internal institusi tersebut. Alur dibawah ini merupakan proses dalam penentuan strategi yang umum dilakukan oleh institusi yang bermain dalam suatu kompetisi, dan peneliti jadikan kerangka dalam mengembangkan strategi BMT untuk mencapai kemajuan dan keberlanjutan institusi dalam jangka panjang.

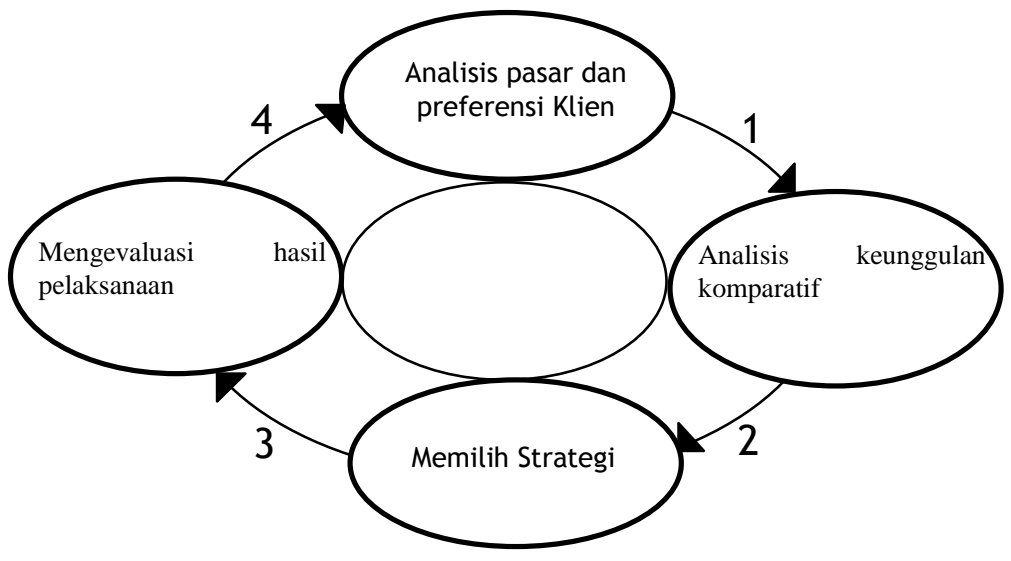

Gambar.4.1. Penetuan strategi

\section{Analisis Pasar dan Preferensi Klien}


Analisis pasar memiliki peran penting dalam mengindentifikasi karakteristik umum, keadaan ekonomi dan sosial dalam suatu masyarakat. Melalui analisis pasar, program microfinance dapat diarahkan untuk memfokuskan segmentasi pasar (target grup/kelompok masyarakat) yang sangat berperan dalam kelanjutan program microfinance. Sehingga pengidentifikasian tersebut dapat menjadi dasar dalam melakukan pengalokasian sumbersumber daya secara efektif.

Aktivitas Microfinance dihadapkan pada keadaan pasar yang informal, yang rentan terhadap kemungkinan asymetri information (Informasi asimetris). Bahaya informasi asimetris ini memiliki implikasi terhadap resiko yang terakumulasi dalam biaya transaksi/ekonomi yang tinggi. Selain itu informasi asimetris sangat menghambat pihak lender untuk menilai prospek serta keadaan klien dengan baik. Oleh karena itu dalam upaya mengatasi dan meminimalisir kemungkinan terhadap bahaya informasi asimetris, maka institusi microfinance diharapkan dapat mengembangkan aksesnya terhadap pusat-pusat informasi di masyarakat yang didukung dengan tokoh masyarakat yang memiliki komitmen tinggi dan cakap serta mampu mengembangkan potensi social capital yang baik ditengah masyarakat.

Analisis preferensi klien bermuara pada dua inti pokok: ekonomi dan demografi. Secara ekonomi penganalisaan preferensi klien diarahkan untuk melihat karakteristik bidang-bidang usaha yang diminati dan populer di masyarakat, sehingga dengan informasi tersebut dapat diidentifikasi jenis-jenis program microfinance apa yang sangat diminati (dibutuhkan). Selanjutnya proses analisis dapat dikembangkan secara spesifik berkaitan dengan aliran pendapatan (cash flow), dari target market microfinance. Hal ini dilakukan untuk menilai seberapa jauh kemampuan klien dalam proses pencicilan dan pembayaran kembali dana pembiayaan. Disisi lain analisis preferensi klien juga harus didasarkan pada ukuran rasionalitas ekonomi yang lazim seperti : aksesibilitas yang mudah, keuntungan ekonomis (keuntungan tinggi, biaya rendah) dan alasan keamanan (security). Analisis demografi dari klien microfinance diarahkan pada beberapa hal seperti: tingkat pendidikan, jenis kelamin serta umur dari kelompok masyarakat yang menjadi target microfinance. Melalui analisis pasar dan klien inilah program-program microfinance dapat dikembangkan lebih lanjut untuk menyesuaikan dengan skim pembiayaan dan karakteristik institusi secara umum. Berikut ini merupakan preferensi klien secara umum dalam menilai produk dan pembiayaan microfinance. 1) Kecil, dalam jumlah pinjaman dan waktu yang relatif pendek, 2) Sederhana, dalam artian proses peminjaman dan 
penilaian kelayakan investasi oleh peminjam tidak rumit, 3) Alternatif, dalam prosedur penilaian penjaminan, 4) Aksesibilitas, dalam lokasi dan pelayanan.

\section{Analisis Keunggulan Komparatif}

Dalam menganalisis keunggulan komparatif antara BMT dengan pesaingnya di pasar keuangan informal, dapat digunakan analisa SWOT untuk mengetahui gambaran umum keadaan persaingan BMT dengan institusi lainnya. Berdasarkan analisis SWOT yang dipaparkan dalam lampiran, secara umum telah dideskripsikan keadaan riil BMT dan kemampuan internalnya dalam menghadapi keadaan peluang dan ancaman dari faktor-faktor eksternal. Hal ini selanjutnya akan dijadikan pedoman dasar untuk mengembangkan strategi lebih lanjut yang berhubungan dengan kemajuan dan keberlanjutan BMT di masa yang akan datang. Dalam analisis SWOT tersebut pembahasan akan dilakukan pada keadaan eksternal/lingkungan ( $\mathrm{O}$ dan $\mathrm{T}$ ) serta keadaan internal (S dan $\mathrm{W}$ ) yang dikembangkan berdasarkan penelitian terdahulu dan pengamatan atas situasi yang dihadapi oleh BMT.

Dalam menganalisis secara keseluruhan eksistensi BMT, dikembangkan beberapa item yang disederhanakan dari analisis SWOT yang telah teridentifikasi. Sehingga dengan penyederhanaan tersebut, dengan mudah dapat dikembangkan strategi yang terfokus pada kelemahan dan pengembangan kelebihan dari keadaan internal BMT. Penyederhanaan analisis tersebut dapat dijabarkan menjadi :

1) Analisis keadaan lingkungan (eksternal), meliputi : Tingkat kompetisi dengan pesaing, kolaborasi (kerja sama) dengan lembaga keuangan, Kebijakan pemerintah serta analisis elemen eksternal lain (ex: Lembaga Swadaya Masyarakat/LSM)

2) Analisis keadaan internal institusi, meliputi : Program pembiayaan dan tabungan, kompetensi manajemen serta pengelolaan keuangan.

\section{Analisis Keadaan Lingkungan (Eksternal)}

Analisis keadaan lingkungan BMT merupakan tahapan identifikasi yang penting untuk mengukur pengaruh keadaan eksternal (peluang dan ancaman) terhadap eksistensi institusi ini sebagai institusi intermediasi keuangan. Beberapa hal penting yang penting dalam proses penganalisaan keadaan eksternal, meliputi : Tingkat kompetisi dengan pesaing, kolaborasi (kerja sama) dengan lembaga keuangan, Kebijakan pemerintah serta analisis elemen eksternal lain (ex: Lembaga Swadaya Masyarakat/LSM). 
Tingkat kompetisi yang dihadapi oleh institusi microfinance (BMT) dapat diukur dari seberapa besar share market yang dikuasai oleh beberapa institusi lain yang identik. Maksudnya adalah seberapa besar dan seberapa banyak jumlah institusi microfinance lain yang beroperasi pada segementasi pasar yang sama dengan BMT. Dengan mengukur tingkat kompetisi insitusiinstitusi microfinance di suatu daerah, maka dapat diukur pengaruhnya terhadap elastisitas permintaan dan kebijakan internal yang sesuai. Kolaborasi (kerja sama) suatu institusi dengan institusi lain merupakan salah satu solusi dalam memperkuat keadaan internal institusi. Hal ini biasanya dilakukan melalui kesepakatan kerja sama dengan institusi keuangan yang lebih besar dalam hal pendanaan/permodalan.

Kebijakan pemerintah (regulasi) dalam pengaturan lembaga keuangan mikro di indonesia saat ini berada dibawah mentri koperasi, sehingga secara umum kelembagaan BMT akan diatur oleh departemen tersebut. Analisis elemen eksternal memiliki pengaruh yang cukup kuat dalam menyokong keberadaan BMT di dalam suatu masyarakat. Beberapa elemen eksternal seperti : LSM (Lembaga Swadaya Masyarakat), Tokoh masyarakat dan Pemerintah daerah, dapat dijadikan sebagai pusat informasi dan media sosialisasi program microfinance yang dikembangkan oleh BMT. Oleh karena itu, setiap institusi microfinance diharapkan dapat membina hubungan yang baik dan harmonis dengan lembaga-lembaga eksternal yang berpengaruh didalam suatu masyarakat.

\section{Analisis Keadaan Internal Institusi}

Analisis keadaan internal institusi (Performing an institutional assesment), meliputi: Produk (Program pembiayaan dan tabungan), Manajerial (Kompetensi manajemen) serta pengelolaan keuangan.

\section{a. Produk (Program Pembiayaan dan Tabungan)}

Program pembiayaan dan tabungan merupakan skim utama lembaga intermediasi microfinance, karena fungsi dari kedua produk ini sangat penting dalam menyediakan fasilitas jasa keuangan bagi aktivitas perekonomian masyarat. Pelayanan dan fasilitas jasa keuangan yang disediakan oleh institusi microfinance tentunya harus berorientasi pada kebutuhan dan preferensi masyarakat yang menggunakannya. Oleh karena itu perencanaan jenis pembiayaan dan produk tabungan selayaknya menjadi perhatian utama institusi microfinance secara bertahap dan berkelanjutan. 
Produk tabungan dan pembiayaan berbasis syariah tentunya merupakan hal yang baru di masyarakat, oleh karena itu pengelolaannya harus diawali dengan tahapan sosialisasi dan pengenalan secara berkala kepada masyarakat. Namun secara sederhana, penilaian suatu produk oleh masyarakat diukur dari seberapa besar nilai ekonomis dan nilai manfaatnya. Variasi jenis-jenis pembiayaan berbasis syariah tentunya dapat menjadi kekuatan dalam pilihan masyarakat dan diversifikasi resiko bagi BMT. Sehingga variasi pembiayaan tersebut dapat disesuaikan dengan kebutuhan masing-masing klien BMT.

Selain dinilai dari besarnya minat masyarakat terhadap produk pembiayaan dan tabungan, tingkat keberhasilan juga harus diukur dengan tingkat efisiensi biaya (Cost) yang harus dikeluarkannya (ex: biaya monitoring/operasional dll). Hal ini disebabkan karena institusi microfinance (BMT) akan dihadapkan pada berbagai kendala teknis yang menelan biaya administrasi dan transaksi yang tinggi. Sebagai contoh dalam pembiayaan Profit Loss Sharing (PLS), resiko yang dihadapi oleh BMT akan lebih tinggi dibandingkan dengan jenis pembiayaan Murabaha, hal ini disebabkan karena dalam jenis pembiayaan PLS besarnya keuntungan sangat tergantung dari kemajuan usaha dan kejujuran klien. Sehingga secara berkala pihak BMT harus melakukan evaluasi dan monitoring untuk menghindari penyalahgunaan oleh pihak pelaksana.

Keuntungan produk dari profit sharing dan buy resell-mark up sangat tergantung dengan kemampuan klien dalam mengembalikan pinjaman, sehingga setiap BMT harus dapat mengukur dengan baik prospek dan kemajuan klien setiap saat. Disisi lain, keuntungan yang didapatkan dari produk sangat bergantung dengan kemauan positif klien yang tercermin dari konsistensi klien dengan akad yang telah dijanjikan. Dengan mengetahui besarnya keuntungan yang didapat dari masing-masing produk pembiayaan tersebut, maka selanjutnya BMT dapat memfokuskan pengalokasian aset dan sumber daya pada unit-unit tersebut.

\section{Manajerial (Kompetensi Manajemen/ Institusi)}

Sisi operasional yang mendukung keberhasilan BMT, memiliki beberapa isu penting berkenaan dengan efektivitas manajerial, SDM (Staf/Karyawan) dan Infrastruktur yang memadai. Keunggulan sisi operasional biasanya mengikuti tren aktivitas pembiayaan yang dilakukan, semakin besar asset yang ada maka keinginan untuk meningkatkan kualitas operasional akan pula disesuaikan. Sebagai institusi yang baru, BMT banyak dihadapkan pada kendala kemampuan staf yang minim pada pemahaman terhadap prinsip syariah. Sehingga seringkali menghambat proses pembiayaan dan pengelolaan manajerial secara umum. 
Kemampuan manajemen dalam berinteraksi dan memberikan pelayanan pada masyarakat, merupakan suatu bentuk kompetensi manajemen dalam menghadapi klien. Hal ini merupakan proses dalam meningkatkan mutu dan image positif suatu institusi microfinance. Dengan semakin meningkatnya kompetensi manajemen, maka eksistensi suatu BMT secara tidak langsung akan berkembang melalui peningkatan pengetahuan dan pengalaman atas preferensi klien dan lingkungan masyarakat.

Di sisi lain lokasi BMT yang strategis merupakan salah satu solusi terbaik dalam memecahkan masalah aksesibilitas klien dengan BMT. Dengan semakin strategisnya lokasi BMT dengan sentra-sentra/pusat ekonomi masyarakat, maka semakin mudah bagi BMT untuk menjangkau dan menggali informasi yang berkenaan dengan klien. Meskipun lokasi yang strategis bukanlah factor utama dalam menopang pengembangan BMT, namun tempat yang strategis dapat mengurangi overhead cost secara umum.

\section{Pengelolaan Keuangan}

Di sisi internal, pengembangan BMT memiliki dasar fungsi sebagai unit ekonomi, yang harus didorong untuk melakukan pengaturan sumber daya yang efisien dan strategi pengembangan yang komprehensif (Baughn et. Al., 1988). Dimana pengembangan strategi yang dimaksud memiliki orientasi pada kebutuhan pasar dan klien, serta memperhatikan aspek efisiensi ekonomis dalam pengelolaan manajerial dan keuangan. Pengelolaan keuangan memiliki orientasi dalam menghasilkan return yang positif secara ekonomis, melalui pengelolaan yang terarah dan dapat dipertanggung jawabkan.

Dalam mengukur keunggulan komparatif internal BMT dalam pengelolaan keuangan, dapat dilihat dari sejauh mana konsistensinya dalam menerapkan prinsip keuangan secara tepat, beretika dan memiliki tanggung jawab sosial pada masyarakat. Prinsip-prinsip pengelolaan keuangan memiliki lingkup yang sangat luas, mencakup : keputusan investasi, pembiayaan dan deviden untuk suatu institusi. Sehingga dengan perencaan yang matang dalam pengelolaan keuangan, maka nilai suatu perusahaan akan semakin meningkat. Seiring dengan tujuan tersebut, peningkatan nilai perusahaan juga harus diimbangi dengan tanggung jawab sosial dan penerapan etika yang baik.

\section{Penentuan dan Pelaksanaan Strategi}

Berdasarkan pengidentifikasian keadaan internal dan pengaruh eksternal yang ada dalam tubuh BMT, terdapat berbagai permasalahan yang kompleks menyangkut kemajuan dan 
keberlanjutan usaha BMT. Namun keadaan ini dapat dijadikan sebagai pedoman dalam memformulasikan strategi yang lebih baik dan komprehensif. Namun dalam pemilihan strategi dan pengaplikasiannya di lapangan dimungkinkan adanya perubahan yang signifikan yang mempengaruhi kondisi lingkungan internal dan eksternal BMT, sehingga pihak manajemen diharapkan untuk terus aktif dalam memperkokoh kekuatan prinsip dan fundamental BMT secara umum.

Dalam penentuan strategi yang tepat bagi BMT diperlukan pemahaman yang komprehensif atas keadaan internal serta eksternal. Di sisi lain pengalaman yang apik atas keberhasilan microfinance konvensional dapat diadaptasi oleh BMT, dengan tetap konsisten dalam koridor dan kerangka yang dapat terima secara prinsip syariah. Sebagai awal langkah strategi, BMT harus memfokuskan pada penterjemahan visi/misi yang mengarah pada pembentukan image positif dengan lingkungan/komunitas market. Hal ini tentu saja harus didukung dengan penguatan struktur fungsi manajemen (staff dan pimpinan) dalam berhubungan dengan klien/market. Sebagai institusi yang tidak hanya menjalankan fungsi Tamwil (Profit), BMT (Baitul Mal wat Tamwil) harus dirangsang untuk melakukan kegiatan yang bersifat sosial (Mal) dari dana yang khusus dihimpun untuk pelaksanaan fungsi tersebut.

Tahap selanjutnya pengembangan strategi BMT lebih diintensifkan dalam beberapa hal, seperti: Prospek bisnis (besarnya penguasaan pasar, kompetisi dan permintaan pelayanan); Kapasitas manajemen (Kepemimpinan dan Pengalaman dalam pengaplikasian pembiayaan Syariah); Operasional (Sistem dan prosedur, Sistem informasi manajemen, akuntabilitas); Resiko (Manajemen Asset dan Liabilitas, efisiensi biaya dan tingkat leverage); Produk dan pelayanan (Tabungan dan pembiayaan). Untuk memfokuskan kajian pengembangan strategi, pelaksanaan fungsi-fungsi BMT harus diorientasikan pada 3 hal utama yaitu : Kekuatan keuangan, Institutional Soundness dan Efek Sosial. Sehingga keberlangsungan BMT dapat optimal mencapai keberhasilan dalam rentangan waktu yang panjang.

\section{Strategi Berkaitan dengan Kekuatan Keuangan}

Sesuai dengan tujuan BMT untuk mencapai kekuatan keuangan (financial viability) dan keberlangsungan profit, diperlukan pemahaman yang utuh mencakup pengetahuan posisi resiko dan keberlangsungan pembiayaan BMT. Hal ini didasarkan pada kelemahan BMT saat ini dalam mengelola asset pembiayaan profit sharing mereka, karena lebih banyak pembiayaan Mark-up (Murabaha) yang dimanfaatkan oleh klien dibandingkan dengan pemanfaatan fasilitas 
pembiayaan profit sharing (Musyaraka dan Mudharabah). Di sisi lain BMT, belum mampu melakukan penguatan modal dari dana pihak ketiga (Capital formation) karena lemahnya akses BMT pada surplus-surplus unit. Penghimpunan dana pihak ketiga dapat diupayakan dengan melakukan kerja sama dengan lembaga keuangan yang lebih besar (ex: Bank syariah), karena pembiayaan tersebut juga diperlukan oleh lembaga tersebut dalam meningkatkan keuntungan dan mendiversifikasikan resikonya. Di sisi lain penghimpunan dana harus diberdayakan dari tabungan masyarakat, untuk menopang kebutuhan pembiayaan di daerah tersebut.

Pelaksanaan pembiayaan oleh BMT membutuhkan berbagai tahapan strategi yang intensif berkaitan dengan proses screening dan monitoring. Pada proses awal screening dimana BMT akan melakukan pembiayaan pada klien, resiko utama yang dihadapi oleh BMT berkaitan dengan permasalahan jaminan (Lack of collateral). Hal ini dapat dimengerti karena sebagian besar dari klien BMT adalah ekonomi usaha kecil, sehingga dibutuhkan pendekatan alternatif untuk menilai prospek klien dengan baik. Pendekatan tersebut dapat disempurnakan dengan mengkaji informasi yang relevan dengan klien seperti : Market klien, Supplier dan institusi formal/informal. Di sisi lain, penilaian kemampuan pembayaran rutin klien dapat didokumentasikan melalui analisis cash flow dan pengeluaran rutin menggunakan harga bayangan.

Selanjutnya proses monitoring atau evaluasi, merupakan kegiatan yang harus kontinyu dilakukan oleh BMT berkenaan dengan keberlanjutan usaha klien dan share profit yang diterima BMT. Oleh karena itu, perhatian BMT tidak boleh luput untuk terus melakukan perbaikan hubungan dengan klien. Proses monitoring dapat dikombinasikan dengan melakukan technical assistance secara kontinu untuk memperkuat kemampuan klien dalam mengelola usahanya. Selan itu pengenalan yang intens pada klien berupa sistem administrasi yang sederhana, perlu dikembangkan agar tidak menghambat proses penghitungan bagi hasil antara klien dan BMT. Kesuksesan proses screening dan monitoring BMT dengan klien, hanya dapat diraih oleh kemampuan manajerial dalam membina hubungan baik dengan klien dan komunitas di sekitarnya.

Tabel 1. Pola Pembiayaan

\begin{tabular}{|l|l|l|}
\hline & Profit Sharing (Mudharabah) & Mark up (Murabaha) \\
\hline \multicolumn{1}{|c|}{ Sangat efektif } & Modal Kerja & Investasi Modal fisik \\
\hline $\begin{array}{l}\text { Biaya untuk } \\
\text { peminjam }\end{array}$ & Tinggi & Rendah \\
\hline
\end{tabular}




\begin{tabular}{|l|l|l|}
\hline $\begin{array}{l}\text { Resiko bagi } \\
\text { peminjam }\end{array}$ & Rendah & Tinggi \\
\hline Resiko bagi BMT & Tinggi & Rendah \\
\hline Biaya Administrasi & $\begin{array}{l}\text { Biaya administrasi yang kompleks. } \\
\text { Seperti : administrasi pinjaman dan } \\
\text { biaya monitoring. Pembayaran yang } \\
\text { variatif berdasarkan profit seringkali } \\
\text { menyulitkan klien untuk } \\
\text { menskedulkan pembayaran }\end{array}$ & $\begin{array}{l}\text { Biaya administrasi dan } \\
\text { monitoring yang rendah karena } \\
\text { teknis pembiayaan yang } \\
\text { sederhana. }\end{array}$ \\
\hline & $\begin{array}{l}\text { Hambatan : Sistem administrasi klien } \\
\text { yang buruk }\end{array}$ & $\begin{array}{l}\text { Hambatan : tidak signifikan } \\
\text { selama pbyran rutin dibayarkan } \\
\text { secara baik }\end{array}$ \\
\hline
\end{tabular}

Orientasi strategi yang komprehensif juga harus dilakukan dengan menjaga keunggulan produk serta kualitas yang terukur dari besarnya keuntungan ekonomis bagi klien dan BMT. Keunggulan produk BMT (Ex: Murabaha/ mark up, Mudharabah/Profit Sharing) yang variatif sangat berkaitan dengan kesesuaian karakteristik usaha klien, sehingga setiap BMT harus dapat memposisikan dengan baik setiap produk dan jenis usahanya. Kesalahan dalam menterjemahkan keinginan pembiayaan klien dapat menjerumuskan klien pada kerugian yang membahayakan keberlanjutan usaha klien. Dalam menentukan jenis pembiayaan yang efektif bagi klien, diperlukan informasi yang baik atas resiko dan keuntungan klien. Pengukuran resiko dan keuntungan BMT tersebut sangat berkaitan dengan besarnya biaya keseluruhan yang diperlukan dalam operasional untuk monitoring dan administrasi selama pembiayaan berlangsun

Dengan skim pembiayaan profit sharing-Mudharabah, pihak BMT menyediakan sepenuhnya dana kepada klien, dan pengelolaan dana tersebut diserahkan sepenuhnya pada klien. Tentu saja pembiyaan ini sangat beresiko, bila BMT tidak mengetahui secara benar prospek dan karakter klien. Di sisi lain share keuntungan yang diprediksi oleh BMT, harus secara benar merefleksikan keuntungan sebenarnya klien. Dalam pembiayaan profit sharing (Mudharabah) biaya evaluasinya lebih tinggi dibandingkan dengan Murabaha. Hanya sedikit BMT syariah yang berani untuk melakukan strategi yang progresif terhadap jenis pembiayaan ini, padahal skim pembiayaan ini (Mudharabah) lebih memberikan hasil yang menguntungkan dibandingkan dengan pembiayaan mark up (Murabaha). Dalam skim mudharabah resiko sepenuhnya dipegang oleh BMT bila resiko tersebut timbul bukan dari kelalaian pengelola (klien), sehingga prinsip kehati-hatian harus difahami oleh klien dan BMT untuk menjaga keberlangsungan profit dari skim pembiayaan tersebut. 
Skim pembiayaan profit sharing lainnya adalah equity participation/Musyaraka, yang membedakan skim ini dengan mudharabah adalah jumlah penyedia dananya yang didukung oleh beberapa pihak serta keterlibatannya dalam pengelolaan manajemen. Sehingga skim pembiayaan musyaraka lebih rendah resikonya dibandingkan dengan mudharabah, karena pembagian resiko disesuaikan dengan jumlah share modal yang diinvestasikan. Dalam jenis pembiayaan ini, penyandang dana memiliki hak untuk ikut serta dalam pengelolaan manajemen usaha, sehingga jenis pembiayaan ini lebih disukai untuk pembiayaan dengan jangka waktu yang lebih panjang. Secara umum jenis-jenis pembiayaan profit sharing sangat tepat digunakan sebagai modal kerja yagn mendukung keberlanjutan dan kemajuan usaha klien, oleh karena itu peran aktif BMT juga dituntut untuk senantiasa membantu klien karena kemajuan klien juga berarti keuntungan bagi hasil bagi BMT.

Dalam menghadapi kebutuhan infrastruktur/investasi fisik klien, skim pembiayaan yang tepat adalah Murabaha. Skim pembiyaan ini adalah jenis pembiayaan yang beresiko rendah, karena kesederhanaan prosedur dan penghitungannya. Jenis pembiayaan mark up ini sangat digemari oleh sebagian besar klien karena sifatnya yang hampir sama dengan bunga (pengembalian yang tetap) namun perbedaannya terletak dalam akad. Namun sesungguhnya variasi skim pembiayaan yang ada dalam BMT, harus disesuaikan dengan kebutuhan dan karakteristik market/klien BMT. Hal ini sebagai antisipasi dalam keberlangsungan pengembalian klien yang wajib disetorkan pada BMT. Oleh karena itu penerapannya harus tetap berpedoman pada prinsip kehati-hatian dan penghitungan yang mantap atas kemampuan klien.

Strategi pembiayaan ideal BMT yang dijelaskan lebih rinci dalam lampiran 3, memaparkan bahwa BMT di masa depan harus lebih berani untuk memperbesar share aktiva produktif dalam pembiayaan profit loss sharing (PLS). Pembiayaan jenis ini selain memberikan tingkat return yang lebih tinggi BMT, juga dinilai lebih menunjukkan eksistensi keterlibatan BMT secara langsung terhadap pengembangan dan kemajuan klien. Namun distribusi pembiayaan ini tidaklah terlepas dari prinsip kehati-hatian dan upaya diversifikasi yang tepat untuk semakin meningkatkan kekuatan dan kelangsungan pembiayaan yang efektif dan menguntungkan.

Strategi pemasaran yang local oriented berdampak pada lemahnya upaya BMT untuk mensosialisasikan produk-produk BMT diluar masyarakat diamana BMT itu berada. Guna 
mengembangkan BMT maka upaya-upaya meningkatkan teknik pemasaran perlu dilakukan, guna memperkenalkan eksistensi BMT di tengah-tengah masyarakat. Di sisi lain dalam pengembangan aspek paradigmatic, diperlukan pengetahuan mengenai aspek bisnis islami sekligus meningkatkan muatan-muatan islam dalam setiap perilaku pengelola dan karyawan BMT dengan masyarakat pada umumnya dan klien pada khususnya.

\section{Strategi yang Berorientasi pada Institutional Soundness}

Atmosfer internal yang kondusif merupakan penggerak utama dalam mengembangkan motivasi bisnis yang lebih maju. Hal ini disebabkan dengan pengembangan internal institusi yang lebih terarah, pelaksanaan fungsi-fungsi strategi manajemen dapat terealisasi secara efektif. Dalam upaya mencapai tujuan tersebut, pengembangan institusi harus diorientasikan pada beberapa hal, seperti : pengembangan struktur organisasi, pengembangan prosedur operasional manajemen, pengembangan budaya organisasi serta peningkatan kontrol manajemen. Hal ini merupakan kunci utama dalam memberikan akses yang baik dalam proses peningkatan pelayanan fasilitas jasa keuangan bagi masyarakat.

Berkaitan dengan hal tersebut, manusia sebagai operator didalamnya tentu memiliki fungsi yang lebih strategis dalam mengemban tugas dan fungsi manajemen tersebut. Oleh karena itu, peran penting seorang pimpinan/manajer dalam mengkondisikan dan mengoptimalkan kemampuan staf-stafnya harus dibangun dengan baik. Selain itu pengembangan institusi harus dioptimalkan dengan kompetensi manajemen yang direfleksikan dalam budaya institusi, seperti : kompetensi staf dan pimpinan terhadap klien dan stakeholder.

Hambatan pengembangan BMT dalam menghadapi market/klien seringkali dihadapkan pada keterbatasan kemampuan manajerial (staff dan pimpinan) dalam mengelola BMT dengan baik. Akibatnya adalah proses strategi BMT tidak terfokus pada keinginan dan kemauan pasar, yang menyebabkan kecilnya market share yang memanfaatkan pembiayaan dan fasilitas produk BMT. Dalam mengembangkan kemampuan manajerial, hal utama yang harus diupayakan adalah mensinergikan kompetensi manajemen dengan market/klien. Perhatian yang penuh atas kompetensi menyangkut penggalian: pengetahuan, keahlian, kemampuan dan prilaku. Sehingga diharapkan dengan kompetnsi yang kuat, BMT dapat lebih bernilai dalam mengejar peluang dan menetralisir ancaman yang datang. Aktivitas riil yang dapat dilakukan untuk mencapai tujuan tersebut adalah dengan melakukan pelatihan intensif dengan topiktopik yang kontributif menggali keunggulan kompetitif internal BMT, seperti : Pendalaman 
prinsip-prinsip syariah, Model-model skim pembiayaan syariah, Serta mempelajari dengan baik strategi marketing yang baik (Produk dan pelayanan). Dalam melakukan strategi marketing tersebut, analisis BMT didasarkan pada kebutuhan market/klien yang berkenaan dengan keinginan produk dan pelayanan yang tepat, seperti: jangka waktu pembiayaan, alternatif jaminan serta strategi “jemput bola”.

Disisi lain dalam upaya pengembangan keadaan internal institusi, orientasi keluar BMT juga harus menjadi perhatian utama institusi ini untuk semakin mengembangkan eksistensinya dalam masyarakat. Peningkatan ini dapat diwujudkan dengan semakin memperbaiki hubungan dengan institusi informal dan formal, yang secara langsung dapat menjadi pusat informasi dalam mengembangkan market channel baik berupa sumber pendanaan/modal, ataupun sebagai relasi dalam mengembangkan potensi masyakat sekitarnya. Melalui prosesproses tersebut diharapkan dapat memperbaiki image/persepsi masyarakat terhadap keberadaan dan eksistensi BMT dalam pendanaan kredit mikro. Hal ini tentunya sangat terkait dengan kompetensi dari setiap elemen dalam BMT untuk concern melakukan inovasi dan pelayanan produk yang terbaik bagi masyarakat.

\section{Pelaksanaan Fungsi Sosial}

BMT sebagai institusi yang tidak hanya berbasis pada keuntungan profit, juga harus diorientasikan pada kehidupan sosial-keagamaan masyarakat. Aktivitas tersebut dapat berupa penampungan dan penyaluran dana masyarkat yang berupa Zakat, Infaq dan Sodaqoh yang ketetapannya secara jelas telah diatur dalam Alqur'an dan Sunah Rasul-Nya. Di sisi lain demi pengembangan kualitas kehidupan masyarakat, kegiatan sosial juga bisa diarahkan untuk memperbaiki kualitas pendidikan dan kesehatan melalui beberapa program-program bantuan khusus yang melibatkan masyarakat mampu. Kegiatan ini sekaligus dapat menegaskan eksistensi BMT sebagai lembaga intermediasi yang tepat untul menyalurkan dana dari surplus unit pada defisit unit, sekaligus menyalurkan dana charity (ZIS) pada orang-orang yang membutuhkan. Dengan konsistensi dan kompetensi yang kontinu untuk mengupayakan kegiatan tersebut, maka BMT dapat terus maju sebagai agen pembangunan sekaligus sebagai institusi profit yang mandiri.

\section{Evaluasi Hasil}

Langkah akhir seusai penentuan dan strategi pelaksanaan adalah evaluasi terhadap hasil yang telah ditetapkan. Pengawasan hasil ini penting untuk mengetahui sejauhmana 
perkembangan kegiatan yang sedang dilakukan sehingga dapat meminimalisasi resiko yang timbul dan tentu juga nantinya diharapkan akan menghasilkan hasil yang lebih optimal.

\section{KESIMPULAN DAN SARAN}

\section{Kesimpulan}

Berdasarkan uraian pada bab-bab terdahulu dapat disimpulkan bahwa strategi pengembangan BMT berorientasi pada kekuatan keuangan (Financial viability), Institutional soundness dan efek sosial. Hal ini tentu saja harus didukung dengan kemampuan analisa fiqh dan ekonomis yang memadai, serta di dorong dengan kekuatan sumber daya yang cukup. Di sisi internal penguatan institusi yang dilakukan pada manajerial dan pengelolaan keuangan harus di tingkatkan untuk memajukan efisiensi BMT dalam pembiayaan kredit bagi sektor kecil menengah.

Penyelenggaraan fungsi manajerial BMT harus merefleksikan kompetensi yang kuat atas keadaan komunitas sekitarnya, sehingga dengan pembinaan hubungan yang baik tersebut dapat diharapkan penterjemahan strategi yang tepat bagi pengembangan BMT. Hal ini diimbangi dengan pengembangan aspek paradigmatic, mengenai aspek bisnis islami sekaligus meningkatkan muatan-muatan islam dalam setiap perilaku pengelola dan karyawan BMT dengan masyarakat pada umumnya dan klien pada khususnya.

Dalam menghadapi persepsi masyarakat yang masih rendah akan kemampuan BMT dan eksistensinya dalam memfasilitasi pembiayaan kredit merupakan hambatan serta tantangan yang harus diantisipasi dengan baik. Sehingga setiap BMT harus konsisten untuk terus melakukan sosialisasi dan strategi pemasaran baik. Selain itu BMT juga dituntut untuk selalu berkompetisi dengan baik, dan aktif dalam menunjukan eksistensinya dalam pembiayaan kredit bagi usaha kecil.

Kami menginventarisir beberapa hal yang harus difahami dengan baik oleh BMT agar mampu bertahan dan konsisten dalam pembiayaan kredit bagi usaha kecil. Hal tersebut antara lain :

1. Implementasi prinsip-prinsip syariah yang utuh

2. Karakteristik pasar keuangan informal yang dominan dengan asymetri information dan biaya transaksi yang tinggi 
3. Kemampuan analisa fiqh dan ekonomis yang baik, untuk mendukung operasional BMT dalam proses dan penyediaan skim pembiayaan yang tepat bagi nasabah

Kemajuan dan keberlanjutan BMT sesungguhnya merupakan keadaan yang dapat terealisasi, apabila pihak pengelola BMT mampu untuk konsisten dalam melakukan strategi yang aktif dalam menyediakan skim pembiayaan yang tepat bagi keperluan klien. Hal ini merupakan proses yang membutuhkan waktu yang lama dan pengorbanan sumber daya yang besar, serta harus berorientasi pada pemahaman serta konsistensi terhadap aplikasi ukhuwah islamiyah.

\section{Saran}

Saran kami dalam pengembangan BMT lebih lanjut antara lain :

1. BMT diharapkan dapat melakukan sosialisasi dan membina hubungan yang baik dengan lingkungan masyarakat, serta mampu secara aktif mengembangkan kerja sama dengan institusi terkait (LSM. Tokoh masyarakat dan pemerintah).

2. BMT diharapkan dapat membina hubungan vertikal dengan lembaga keuangan yang lebih besar, dalam upaya mendukung pendanaan modal pembiayaan/investasi.

3. BMT diharapkan dapat mengupgrade sumber daya manusia secara efektif melalui pelatihan dan pengembangan budaya instusi yang kondusif.

4. BMT diharapkan dapat mengembangkan kemampuan inovasi dalam produk (pembiayaan dan tabungan) yang lebih menarik dan conditional dengan preferensi/kebutuhan klien.

\section{DAFTAR PUSTAKA}

.Best Practices in Microfinance Facilitating the provision of financial services

to low income families. End Poverty Foundations. USA.

.Blue Print Pengembangan Bank Syariah di Indonesia. Bank Indonesia (BI), Jakarta. . Progress Toward Microfinance Commercializxation

.The Russian Microfinance Project. Document 52. A U.S. Department of State/NISCUP Funded Partnership among the University of Washington-Evans School of Public Affairs. The Siberian Academy of Public Administration, and the Irkutsk State University

.Initial Training Program Development. 1999. Access to Microfinance \& Improved Implementation of PolicyReform (AMIR Program)

.Analisa preferensi masyarakat terhadap lembaga keuangan syariah (penelitian Bank Indonesia) di empat propinsi di pulau jawa. 2000 
2001. Ekonomi Islami Suatu Kajian Makro. IIIT Indonesia, Jakarta.

. 2001.Ekonomi Mikro Islami. IIIT Indonesia, Jakarta.

2003.Bank Islam : Analisa Fiqih dan Keuangan. IIIT Indonesia, Jakarta.

Ahmed, Habib. Financing Microenterprises: an Analytical Study of Islamic Microfinance institution (tidak dipublikasikan)

Antonio, M Syafi'i. 2002. Bank Syariah Dari Teori Ke Praktik. Jakarta: Gema Insani Press.

Baraba , Achmad., Buletin ekonomi moneter perbankan vol 2, No. 3. 1999. Bank Indonesia, Jakarta.

Baughn, et, al. The Bankers Handbook. 1988. Third edition. Amerika: Dow Jones Irwin.

Baydas, Mayada. 1997. Commercial Bank in Microfinance : New Actors in the Microfinance World. MBP Project

Chapra, M Umar. 2001. Masa Depan Ilmu Ekonomi Sebuah Tinjauan Islam). Jakarta: Gema Insani Press.

Dhumale, Rahul and Amela Sapcannin. An Aplication of Islamic Banking Principles to Microfinance, Technical note. World Bank.

Freddy Rangkuti. 1999.Analisa SWOT Teknik Membedah Kasus Bisnis. Jakarta; Penerbit Pt. Gramedia Pustaka Utama.

Ibrahim, Maulana. 2002.Risk Management: Islamic Financial Policies. Penelitian oleh Bank Indonesia. Jakarta.

Ilmi, Makhalul SM. 2002. Teori dan Praktek Lembaga Keuangan Mikro Syariah. Yogyakarta: UII Press.

Karim, Adiwarman. 2001.Ekonomi Islam Suatu Kajian Kontemporer. Jakarta: Gema Insani Press.

Kuncoro, Mudrajat. 1997. Ekonomi Pembagunan. Yogyakarta: UPP AMP YKPN.

Martowijoyo, Sumantoro. 2001. Perbankan dan Usaha Kecil : Keberpihakan. keterkaitan dan keterpaksaan ?. Pengembangan Perbankan (Mei-juni no.89)

Miles, Mathew B, dan A. Michael Hubermen. , Analisa Data Kualitatif. Peterjemah. Tjejep Rohendi. 1992. UI-Press. Jakarta.

Moloeng, Lexy J. 1994. Metodologi Penelitian Kualitatif. Bandung: Remaja Rosdakarya.

Muhamad. 2002. Manajemen Bank syari'ah. UPP AMP YKPN. Yogyakarta.

Nawawi, Hadari. 1993. Metodologi Penelitian Bidang Sosial. Yogyakarta: Gadjah Mada University Press.

Natilson, Nancy., Pro Mujer Tillman A. Bruett. 2001.Financial Performance Monitoring: A Guide for Board Members of Microfinance Institutions. USA.

Nazir. 1999. Metodologi Penelitian. Jakarta: Ghalia Indonesia.

Pearce, et, al. 1997. Manajemen Strategik : formulasi. implementasi dan pengendalian. Jakarta: Binarupa Aksara. 
Rudjito. Strategi Dalam Menanggulangi Kemiskinan. di Sampaikan pada Seminar Menanggulangi Kemiskinan melalui The Estabilishment of asean anti-poverty bank yang diselenggarakan oleh badan kerjasama antara parlemen DPR-RI. selasa 28 Januari 2003 di Jakarta.

Santoso, Hurip. 2001. Analisis Keterkaitan Kompetensi dengan Kinerja Keuangan. Tesis Magister Manajemen Universitas Diponegoro. Semarang

Siamat, Dahlan. 1999.Manajemen Lembaga Keuangan. edisi kedua. Lembaga Penerbit Fakultas Ekonomi Universitas Indonesia. Jakarta.

Siddiqi, Muhammad Najatullah. 1984.Bank Ilam. Bandung: Penerbit Pustaka.

Simanjuntak, Payaman J. 1985. Pengantar Ekonomi Sumber Daya Manusia. Jakarta: Lembaga Penerbit Ekonomi Universitas Indonesia.

Siregar, Mulya. Bank Syariah : Solusi Permasalahan Perbankan Nasional ?. 2001. Pengembangan perbankan (Mei-Juni No.89)

Sudarsono, Heri. 2003. Bank dan Lembaga Keuanagn Syariah. Yogyakarta: EKONISIA Kampus FEUII.

Timberg.,Thomas. 2002. Risk Management: Islamic Financial Policies. Penelitian oleh USAID. Jakarta

Umar, Husein. 2002.Strategic Management in Action. Jakarta: Gramedia.

Widyaningrum, Nurul. 2002. Model Pembiayaan BMT dan Dampaknya Bagi Usaha Kecil (Studi Kasus BMT Dampingan Yayasan Peramu Bogor). Bandung: Yayasan AKATIGA.

Zaenal. 2001. Menilai Tingkat Kesehatan BMT dari Aspek Manajemen. $h t t p: \backslash \backslash w w w . t a z k i a o n l i n e . c o m$ 